\title{
Investigation of Stability and Power Consumption of an AlGaN/GaN Heterostructure Hydrogen Gas Sensor Using Different Bias Conditions
}

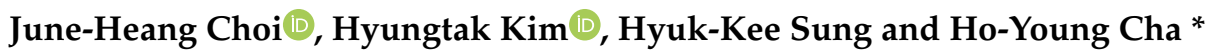 \\ School of Electronic and Electrical Engineering, Hongik University, Seoul 04066, Korea; \\ petrus0314@mail.hongik.ac.kr (J.-H.C.); hkim@hongik.ac.kr (H.K.); hksung@hongik.ac.kr (H.-K.S.) \\ * Correspondence: hcha@hongik.ac.kr
}

Received: 13 November 2019; Accepted: 13 December 2019; Published: 16 December 2019

\begin{abstract}
A Pd-functionalized hydrogen gas sensor was fabricated on an AlGaN/GaN-on-Si heterostructure platform. The AlGaN layer under the Pd catalyst area was partially recessed by plasma etching, which resulted in a low standby current level enhancing the sensor response. Sensor stability and power consumption depending on operation conditions were carefully investigated using two different bias modes: constant voltage bias mode and constant current bias mode. From the stability point of view, high voltage operation is better than low voltage operation for the constant voltage mode of operation, whereas low current operation is preferred over high current operation for the constant current mode of operation. That is, stable operation with lower standby power consumption can be achieved with the constant current bias operation. The fabricated AlGaN/GaN-on-Si hydrogen sensor exhibited excellent sensing characteristics; a response of $120 \%$ with a response time of $<0.4 \mathrm{~s}$ at a bias current density of $1 \mathrm{~mA} / \mathrm{mm}$ at $200{ }^{\circ} \mathrm{C}$. The standby power consumption was only $0.54 \mathrm{~W} / \mathrm{cm}^{2}$ for a sensing catalyst area of $100 \times 24 \mu \mathrm{m}^{2}$.
\end{abstract}

Keywords: AlGaN/GaN heterostructure; hydrogen sensor; power consumption; stability; current mode operation

\section{Introduction}

Recently, hydrogen has attracted much attention as a new energy source, and extensive research has been conducted [1] into its use. Hydrogen is used as the material for fuel cells and has been highlighted as a pollution-free natural energy source [2]. However, great care must be taken with regard to the usage and handling of hydrogen because it is easily oxidized and explodes even at low concentrations of the order of $\sim 4 \%$ [3]. Therefore, reliable hydrogen gas sensors with fast response characteristics are required to identify and prevent hydrogen leakage in fuel cells.

Semiconductor-based gas sensors have the benefits of low cost, small size, and low power consumption. Various semiconductor materials have been utilized to implement hydrogen sensors [4-10], among which $\mathrm{GaN}$ is an attractive material for a hydrogen sensor operating at high temperatures because of its wide energy bandgap with low intrinsic carrier density [11-13]. The low intrinsic carrier density allows $\mathrm{GaN}$ to maintain its semiconductor properties in high-temperature environments. Therefore, $\mathrm{GaN}$ is suitable for use as a gas sensor platform in cases where the gas-catalyst reaction processes require high temperatures. $\mathrm{AlGaN} / \mathrm{GaN}$ heterostructure materials have the added benefit of high electron concentrations of a two-dimensional electron gas channel with a high channel mobility of $>1500 \mathrm{~cm}^{2} / \mathrm{V} \cdot \mathrm{s}$, which enhance the response speeds. 
In this study, $\mathrm{AlGaN} / \mathrm{GaN}$ heterostructure-based hydrogen gas sensors were fabricated using a Pd catalyst. Further, we investigated the sensing characteristics using both voltage and current bias mode operations.

\section{Experiments}

\subsection{Sensor Fabrication}

Field-effect transistor (FET)-type hydrogen gas sensors were fabricated on an AlGaN/GaN-on-Si heterostructure substrate. The epitaxial structure consisted of a $10 \mathrm{~nm}$ in situ $\mathrm{SiN}_{\mathrm{x}}$ passivation layer, a $3.5 \mathrm{~nm} \mathrm{GaN}$ cap layer, a $23 \mathrm{~nm} \mathrm{Al} \mathrm{Al}_{0.24} \mathrm{Ga}_{0.76} \mathrm{~N}$ barrier layer, a $420 \mathrm{~nm}$ i-GaN layer, and a $4.2 \mu \mathrm{m} \mathrm{GaN}$ buffer layer on a $1000 \mu \mathrm{m}$ thick (111)-oriented silicon substrate. The sensor fabrication process is schematically illustrated in Figure 1. After solvent cleaning, the ohmic contact areas were defined by photolithography, and the exposed in-situ $\mathrm{SiN}_{\mathrm{x}}$ layer and underlying epitaxial layers were etched down to the middle of the AlGaN barrier layer using $\mathrm{CF}_{4}$ and $\mathrm{Cl}_{2} / \mathrm{BCl}_{2}$-based inductively-coupled plasma-reactive ion etching (ICP-RIE), respectively, prior to ohmic metal deposition. After Ti/Al/Ni/Au (= 200/1200/250/500 $\AA$ ) metallization, rapid thermal annealing was carried out at $830^{\circ} \mathrm{C}$ for $30 \mathrm{~s}$ in $\mathrm{N}_{2}$ ambient to achieve low ohmic contact resistance. The measured contact resistance and sheet resistance were $0.56 \Omega \cdot \mathrm{mm}$ and $117 \Omega / \mathrm{sq}$, respectively. After an additional photolithography process, a Ti/Au $(=20 / 250 \mathrm{~nm})$ metal stack was evaporated for the pad electrodes. MESA isolation with an etch depth of $350 \mathrm{~nm}$ was conducted using the same etching process described above. After defining the catalyst area, the exposed in-situ $\mathrm{SiN}_{\mathrm{x}}$ layer and underlying epitaxial layers were also etched using the same process. The remaining AlGaN barrier layer thickness under the catalyst area was $6 \mathrm{~nm}$. The thinned AlGaN barrier layer has the advantage of low standby current level that can enhance the response of the device. A $30 \mathrm{~nm}$ thick Pd film was evaporated for the catalyst material; Pd is an excellent catalyst for hydrogen because of its high solubility of hydrogen [14]. A $100 \mathrm{~nm} \mathrm{SiN}$ film was deposited at $190{ }^{\circ} \mathrm{C}$ using the plasma-enhanced chemical vapor deposition technique for surface passivation. The catalyst window area $\left(=24 \times 100 \mu \mathrm{m}^{2}\right)$ for gas reaction was defined by a $\mathrm{CF}_{4}$ based $\mathrm{SiN}_{\mathrm{x}}$ etching process, during which the pad contact areas were also opened. The fabricated sensor structure and its microscopic image are shown in Figure 2a,b, respectively.

(a) Ohmic contact

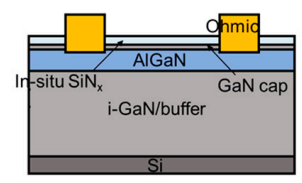

(b) MESA isolation

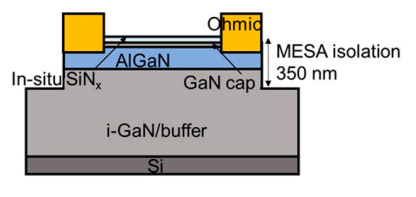

(c) Recess and catalyst formation

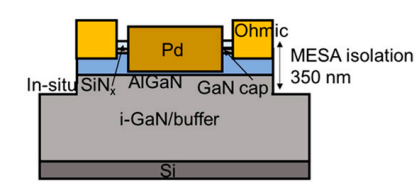

(d) Pad electrode

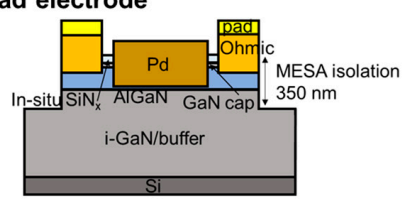

(e) $\mathrm{SiN}_{\mathrm{x}}$ passivation

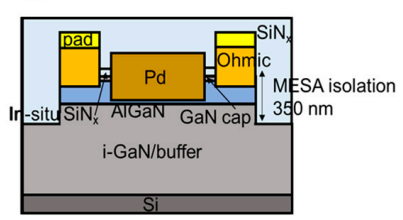

(f) Open catalyst window and contacts

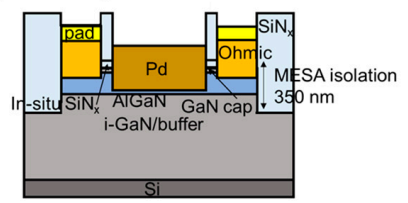

Figure 1. Fabrication process of a Pd-functionalized AlGaN/GaN-on-Si hydrogen sensor: (a) Ohmic contact, (b) MESA isolation, (c) recess and catalyst formation, (d) pad electrode, (e) $\mathrm{SiN}_{\mathrm{x}}$ passivation, and (f) open catalyst window and contacts. 
(a)

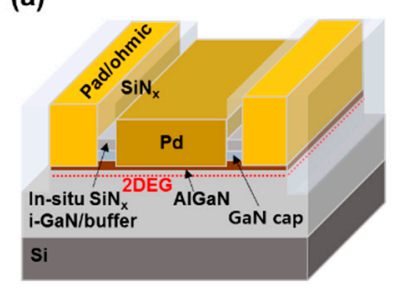

(b)

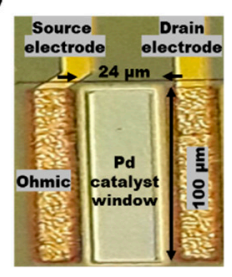

(c)

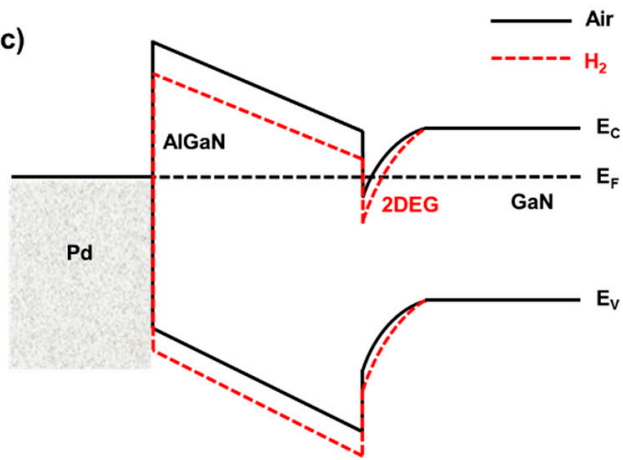

Figure 2. (a) 3D schematic of Pd-functionalized AlGaN/GaN-on-Si hydrogen sensor, (b) microscopic top view of a fabricated sensor, and (c) change of $\mathrm{AlGaN} / \mathrm{GaN}$ energy band structure with hydrogen absorption.

\subsection{Sensor Characterization}

Pd has high solubility to hydrogen and has phase transition characteristics with hydrogen atoms [15]. When hydrogen gas is introduced to the Pd catalyst, the hydrogen molecules are adsorbed on $\mathrm{Pd}$ and decomposed into atoms that are rapidly dissolved in $\mathrm{Pd}$. As a result, $\alpha$-PdH and $\beta-\mathrm{PdH}$ can be produced by the following reaction mechanism where more $\beta$-phase can be produced with increasing temperature [16].

$$
\left[\left(\mathrm{Pd}+\mathrm{H}_{2} \underset{a}{\rightarrow} \alpha-\mathrm{PdH}\right)+\mathrm{H}_{2} \underset{b}{\rightarrow} \beta-\mathrm{PdH}\right] .
$$

The $\beta$-phase has a larger lattice constant that increases hydrogen solubility [17]. As a result, hydrogen permeability increases with increasing temperature [18]. The dipole effects of the hydrogen atoms absorbed in Pd lower the surface potential of the AlGaN barrier layer, as illustrated in Figure 2c, which increases the two-dimensional electron gas concentration at the AlGaN-GaN interface. Consequently, the sensor current level increases with hydrogen absorption. This reaction is reversible and can recover the initial state when the hydrogen supply is terminated.

The fabricated sensor was placed in a gas chamber whose temperature was controlled by a heater module located below the chamber plate. Hydrogen gas at a concentration of $4 \%$ was used for sensor characterization, and the chamber temperature was varied from room temperature to $250{ }^{\circ} \mathrm{C}$.

\section{Results and Discussion}

First, we investigated the current-voltage characteristics of the sensor, where the sensor was biased by a voltage supply and the current between the two electrodes was measured. Figure 3a-e shows the current-voltage characteristics at different temperatures with and without hydrogen injection. The measurements were repeated five times to assess reproducibility. The current level was observed to increase with hydrogen injection regardless of the temperature, which could be associated with the reduced surface potential due to the $\mathrm{Pd}-\mathrm{H}$ chemical reaction. It should be noted that the current level changed slightly at room temperature and at $100^{\circ} \mathrm{C}$ as the measurements were repeated, whereas no variations were observed at temperatures of $150^{\circ} \mathrm{C}$ and higher.

The sensing response under the constant voltage bias operation can be defined by [19]

$$
\text { Response }[\%]=\left(\frac{I_{g a s}-I_{a i r}}{I_{\text {air }}}\right) \times 100 \text {, }
$$

where $I_{g a s}$ is the current measured with hydrogen injection and $I_{a i r}$ is the standby current without hydrogen injection. The bias-voltage-dependent response characteristics are shown in Figure $3 \mathrm{f}$ as a function of the temperature. The response increased with temperature up to $200{ }^{\circ} \mathrm{C}$, beyond which a relatively smaller increase was observed. The increase in response at elevated temperatures was 
associated with the enhanced dissociation of hydrogen molecules [18] The lower standby current at elevated temperatures was attributed to the lower channel mobility caused by photon scattering. It should also be noted that the response current level also decreased at elevated temperatures. Therefore, there is a trade-off for the sensor response between hydrogen permeability and mobility reduction with increasing temperature. The slower increase in response beyond $200{ }^{\circ} \mathrm{C}$ was associated with significant reduction in mobility [20]. A maximum response of $180 \%$ was achieved at $250{ }^{\circ} \mathrm{C}$ with a bias voltage of $1 \mathrm{~V}$. However, it is suggested that the optimum reaction temperature is $200{ }^{\circ} \mathrm{C}$, considering the power consumption of the heater module that has to be built into the sensor system.

(a)

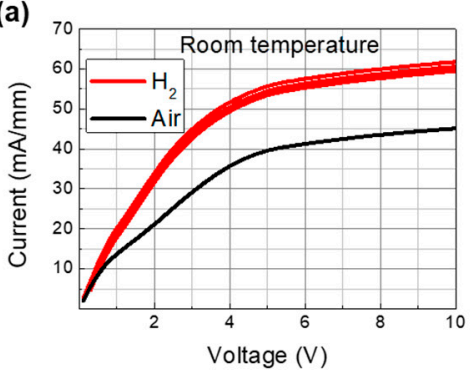

(d)

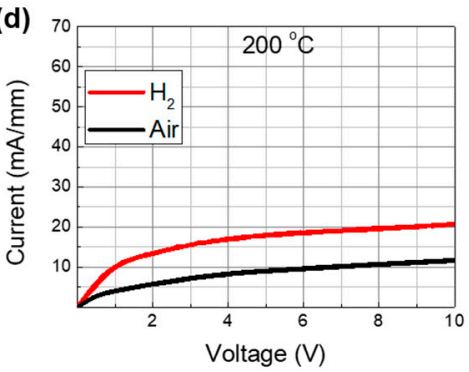

(b)

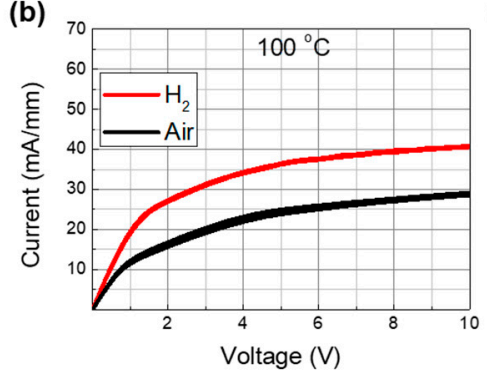

(e)

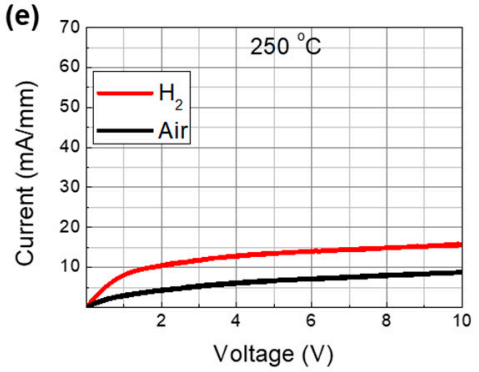

(c)

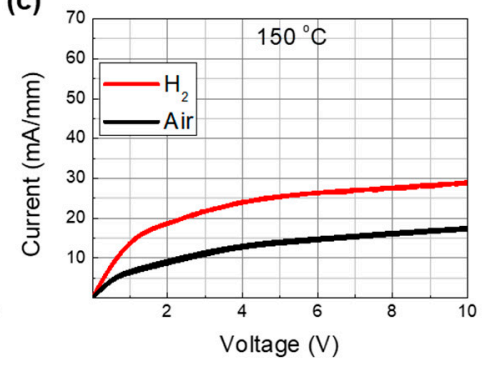

(f)

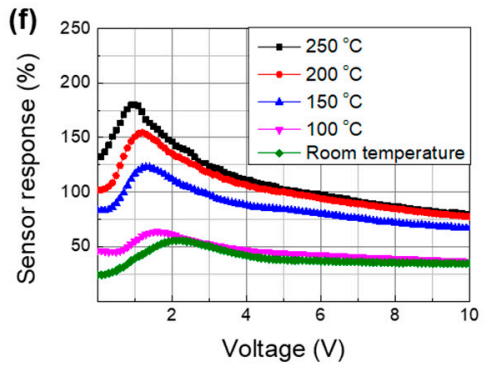

Figure 3. Current-voltage characteristics of the fabricated Pd-functionalized AlGaN/GaN-on-Si hydrogen sensor with and without hydrogen injection at various temperatures: (a) Room temperature, (b) $100{ }^{\circ} \mathrm{C}$, (c) $150{ }^{\circ} \mathrm{C}$, (d) $200{ }^{\circ} \mathrm{C}$, and (e) $250{ }^{\circ} \mathrm{C}$. (f) Response characteristics of the fabricated Pd-functionalized AlGaN/GaN-on-Si hydrogen sensor versus bias voltage as a function of temperature, which were extracted from (a) to (e).

Since the response depends strongly on the bias voltage, it is better to set the bias voltage in the stable region rather than at the maximum point because the sensor signal might drift over time. For comparison, we chose two bias conditions of the constant voltage bias operation for the stability test: The first was at $1 \mathrm{~V}$ with maximum response and the second was at $9 \mathrm{~V}$ in the saturation region. In order to investigate the stability of the sensor signal, sensing repeatability tests were carried out as follows. Hydrogen gas was introduced for $5 \mathrm{~s}$, paused for $55 \mathrm{~s}$, and the process was repeated for $30 \mathrm{~min}$. Figure $4 \mathrm{a}, \mathrm{b}$ shows the repeatability characteristics measured at the bias voltages of $1 \mathrm{~V}$ and $9 \mathrm{~V}$, respectively. Although the response was high at the low bias voltage condition (i.e., $1 \mathrm{~V}$ ), the sensing environment conditions, including the bias voltage fluctuation, caused noticeable differences. On the other hand, the response at the high voltage bias condition (i.e., $9 \mathrm{~V}$ ) was less dependent of the bias voltage fluctuation, which is expected to result in more stable operation. The variation ranges in the peak sensing and bottom recovery current levels with a bias voltage of $1 \mathrm{~V}$ were 0.4 and $1.0 \mathrm{~mA} / \mathrm{mm}$, respectively, whereas those for the bias voltage of $9 \mathrm{~V}$ were 0.2 and $0.1 \mathrm{~mA} / \mathrm{mm}$, respectively. It should be noted that the most significant drawback of the high voltage bias operation is the relatively higher standby power consumption owing to the higher standby current and voltage levels. The standby power consumption for 1 and $9 \mathrm{~V}$ operations were 3.4 and $97.2 \mathrm{~mW} / \mathrm{mm}$, respectively, where the area was defined by the catalyst area. The response transient characteristics are shown in the magnified plots located on the right-hand side. The response times for both bias conditions were less than $0.4 \mathrm{~s}$. 
(a)
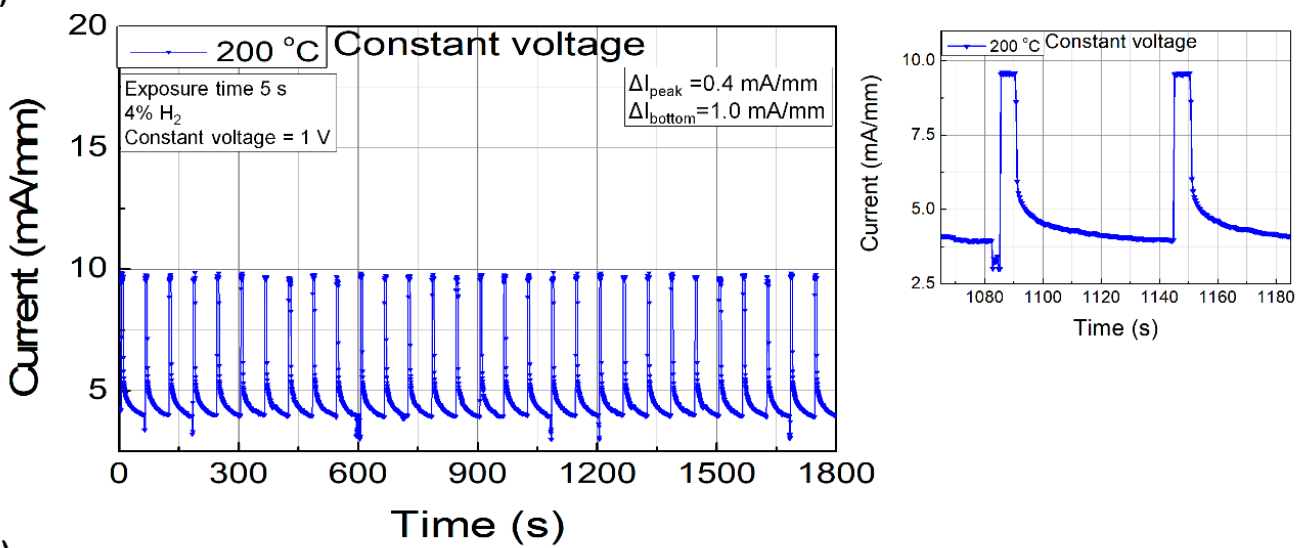

(b)
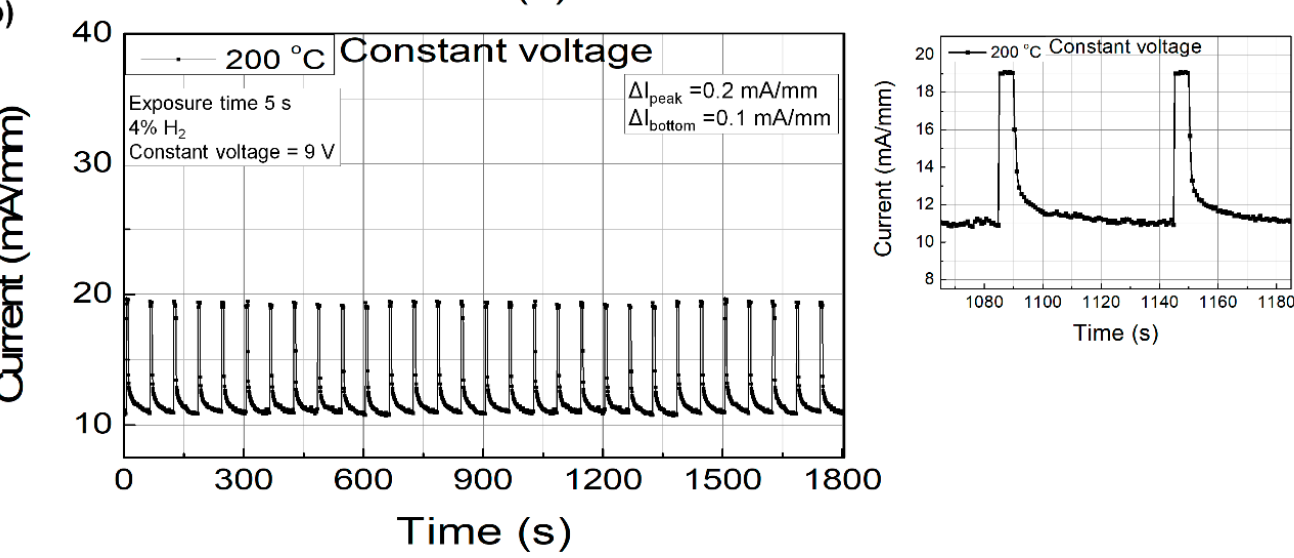

Figure 4. Sensing repeatability characteristics of the fabricated Pd-functionalized AlGaN/GaN-on-Si hydrogen sensor with bias voltages of (a) $1 \mathrm{~V}$ and (b) $9 \mathrm{~V}$. The measurement temperature was $200{ }^{\circ} \mathrm{C}$.

The sensitivity characteristics were investigated with various hydrogen concentration using the stable bias condition of $9 \mathrm{~V}$. Figure 5a shows the sensor response versus hydrogen concentration. The hydrogen concentration was varied from 1000 to $40,000 \mathrm{ppm}$. The sensitivity can be defined by the sensor output response as a function of the measurand applied to the input [21]. We used the change in the sensor current level as the output response and the hydrogen concentration as the input measurand. As plotted in Figure 5b, a linear relationship between the response current change and the hydrogen concentration was observed up to $6000 \mathrm{ppm}$, beyond which the increase in the response current became smaller. The sensitivity was $1 \mu \mathrm{A} / \mathrm{mm} \cdot \mathrm{ppm}$, which was derived from the linear regime.

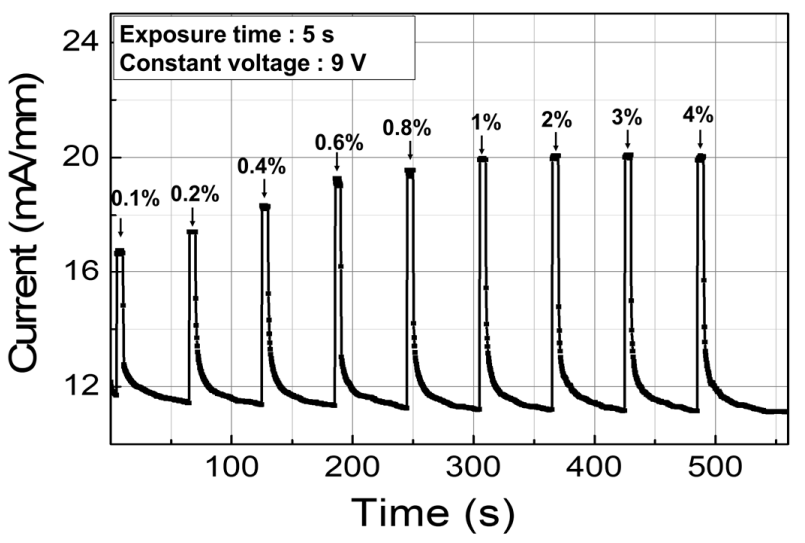

(a)

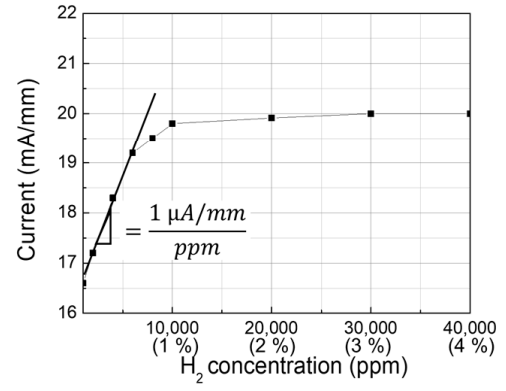

(b)

Figure 5. (a) Response characteristics as a function of hydrogen concentration and (b) their corresponding response plot. 
We also investigated the current-dependent response characteristics, wherein the sensor was biased by a current supply and the voltage between the two electrodes was measured. Figure 6a-e shows the voltage-current characteristics at different temperatures with and without hydrogen injection. The measurements were repeated five times. The voltage levels decreased with hydrogen injection. Similar to the constant voltage operation case, the current-voltage characteristics at lower temperatures were relatively unstable and those at 200 and $250{ }^{\circ} \mathrm{C}$ were stable.

(a)

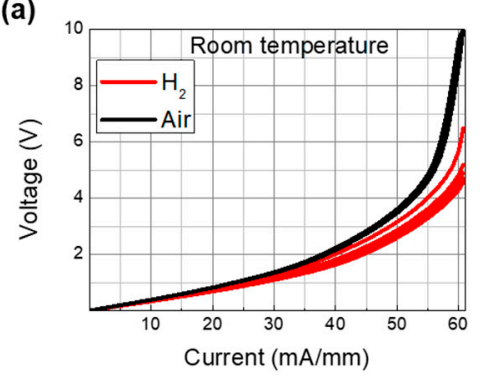

(d)

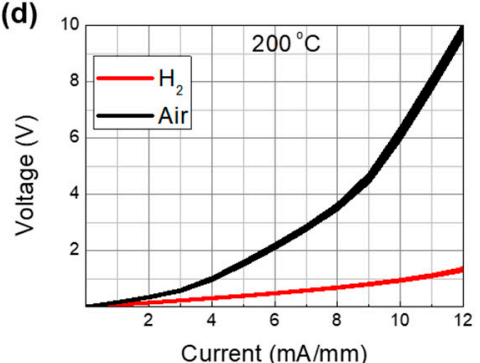

(b)

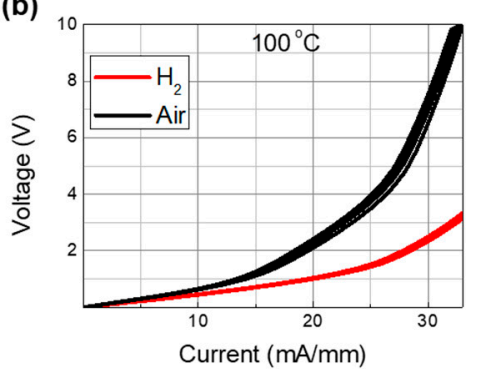

(e)

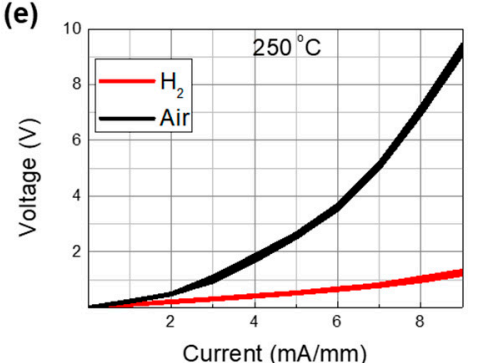

(c)
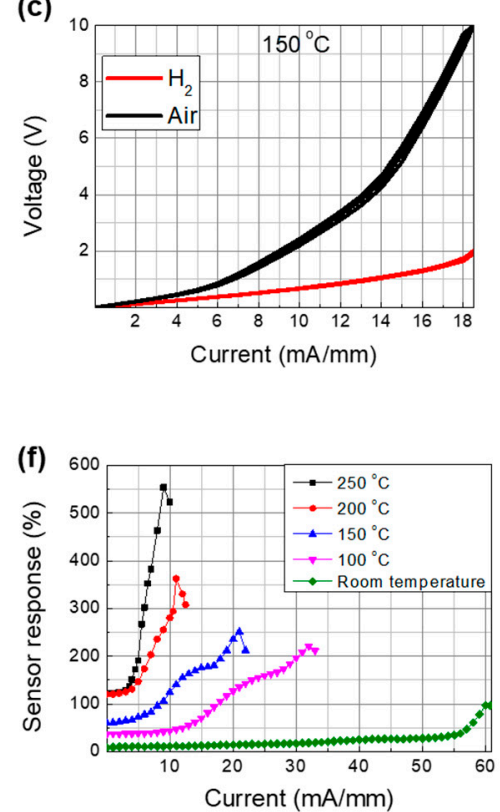

Figure 6. Voltage-current characteristics of the fabricated Pd-functionalized AlGaN/GaN-on-Si hydrogen sensor with and without hydrogen injection at various temperatures: (a) Room temperature, (b) $100{ }^{\circ} \mathrm{C}$, (c) $150{ }^{\circ} \mathrm{C}$, (d) $200{ }^{\circ} \mathrm{C}$, and (e) $250{ }^{\circ} \mathrm{C}$. (f) Response characteristics of the Pd-functionalized $\mathrm{AlGaN} / \mathrm{GaN}-\mathrm{on}-\mathrm{Si}$ hydrogen sensor versus bias current as a function of temperature, which were extracted from (a) to (e).

The sensing response under the constant bias current mode operation can be defined by [22]

$$
\text { Response }=\left(\frac{V_{a i r}-V_{g a s}}{V_{g a s}}\right) \times 100 \text {, }
$$

where $V_{\text {air }}$ is the standby voltage without hydrogen injection and $V_{g a s}$ is the voltage measured with hydrogen injection. The current-dependent response characteristics are plotted in Figure $6 \mathrm{f}$ as a function of temperature. The response increased significantly with temperature up to $200{ }^{\circ} \mathrm{C}$ and a relatively lower increase was observed at $250{ }^{\circ} \mathrm{C}$.

For comparison, we chose two bias conditions of the constant current bias operation for the stability test at $200{ }^{\circ} \mathrm{C}$ : The first at $1 \mathrm{~mA} / \mathrm{mm}$ in the stable region and the second at $11 \mathrm{~mA} / \mathrm{mm}$ in the high-response region. Similar to the constant voltage mode tests, the sensing repeatability tests were carried out with hydrogen injection of $5 \mathrm{~s}$ and a period of $60 \mathrm{~s}$ for $30 \mathrm{~min}$. Figure 7a,b shows the repeatability characteristics measured at bias currents of 1 and $11 \mathrm{~mA} / \mathrm{mm}$, respectively. Although the response was much higher for the bias current of $11 \mathrm{~mA} / \mathrm{mm}$, significant fluctuations were observed over the duration of the test. On the other hand, very stable operation was observed at $1 \mathrm{~mA} / \mathrm{mm}$. The variation ranges for the peak recovery and bottom sensing voltage levels with the bias current of $1 \mathrm{~mA} / \mathrm{mm}$ were 1.21 and $1.12 \mathrm{mV}$, respectively, whereas those with the bias current of $11 \mathrm{~mA} / \mathrm{mm}$ were 33 and $709 \mathrm{mV}$, respectively. The standby power consumption for the 1 and $11 \mathrm{~mA} / \mathrm{mm}$ operations were 0.15 and $85 \mathrm{~mW} / \mathrm{mm}$, respectively. Based on our experiments, it is suggested that the 
constant current operation with low bias current level is a good choice for both stable and low power consumption operation.

(a)
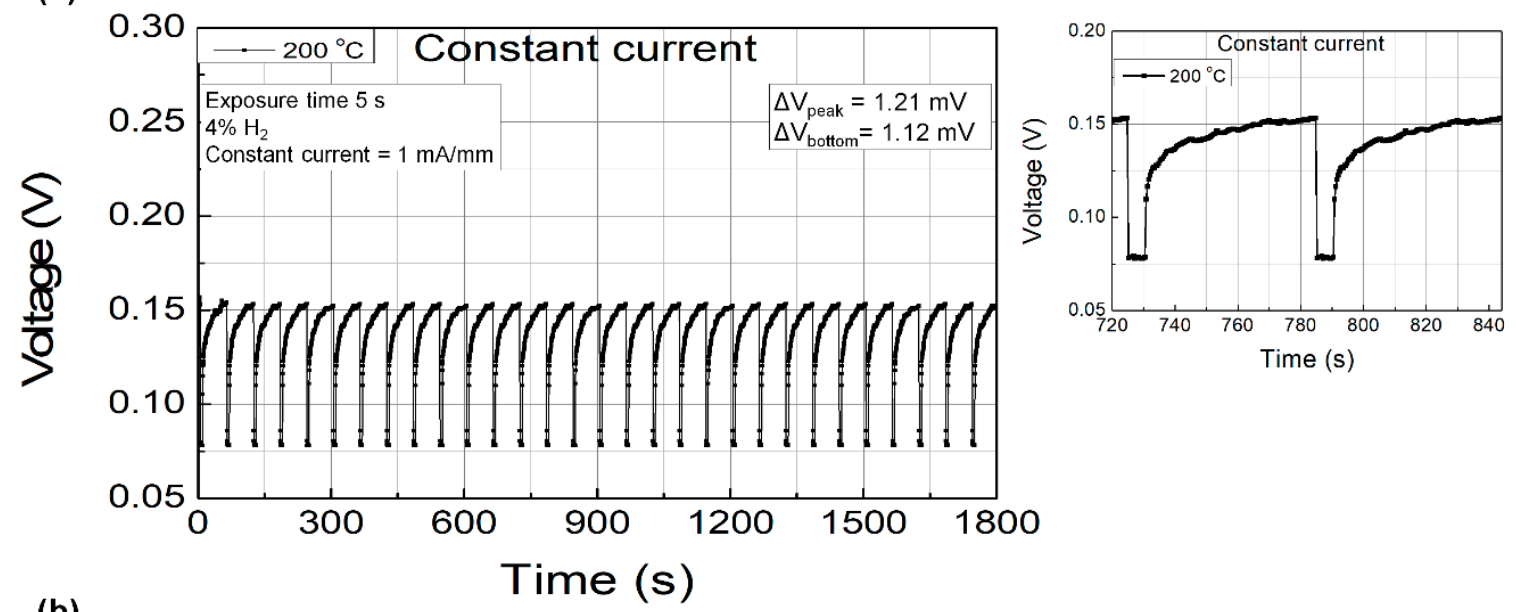

(b)
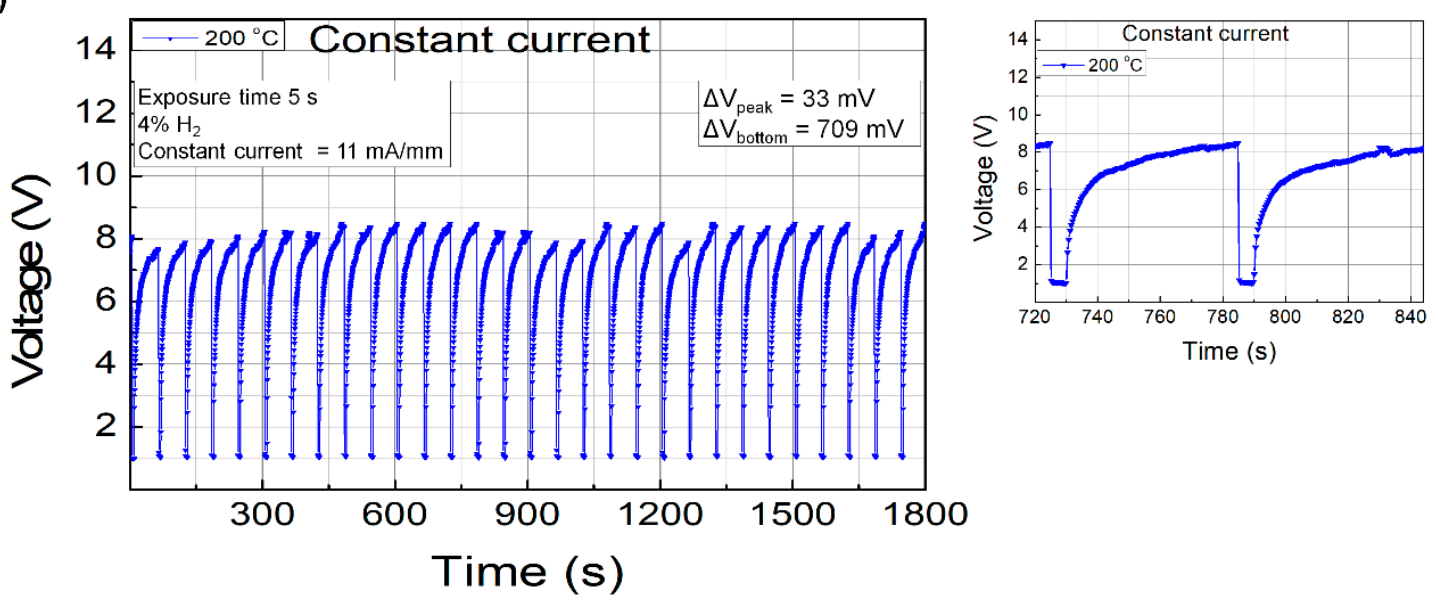

Figure 7. Sensing repeatability characteristics of the fabricated Pd-functionalized AlGaN/GaN-on-Si hydrogen sensor with bias currents of (a) $1 \mathrm{~mA} / \mathrm{mm}$ and (b) $11 \mathrm{~mA} / \mathrm{mm}$. The measurement temperature was $200{ }^{\circ} \mathrm{C}$.

The sensitivity characteristics were investigated with various hydrogen concentration using the stable bias condition of $1 \mathrm{~mA} / \mathrm{mm}$. Figure 8 a shows the sensor response versus hydrogen concentration. The hydrogen concentration was varied from 1000 to $40,000 \mathrm{ppm}$. In order to extract the sensitivity, we used the change in the sensor voltage level as the output response and the hydrogen concentration as the input measurand. As plotted in Figure $8 b$, a linear relationship between the response voltage change and the hydrogen concentration was observed from 2000 to $10,000 \mathrm{ppm}$, beyond which the increase in the response voltage became smaller. The sensitivity was $-1.75 \mu \mathrm{V} / \mathrm{ppm}$, which was derived from the linear regime.

The response and recovery transient characteristics are shown in the magnified plots located on the right-hand side. Definition of response time and recovery time used in this study are illustrated in Figure 9. The response times for both bias conditions were very fast, which were shorter than the sampling period (i.e., $0.4 \mathrm{~s}$ ). The recovery seemed to be slow, but it should be noted that it takes a long time for the remaining gas inside the gas line to be evacuated completely after the value is closed by a controller. Therefore, the actual recovery times would be much shorter.

In Table 1, the sensor characteristics are compared with other reports made on FET and diode-type hydrogen sensors. Our prototype sensor exhibited excellent sensor response characteristics as well as low standby power consumption. 


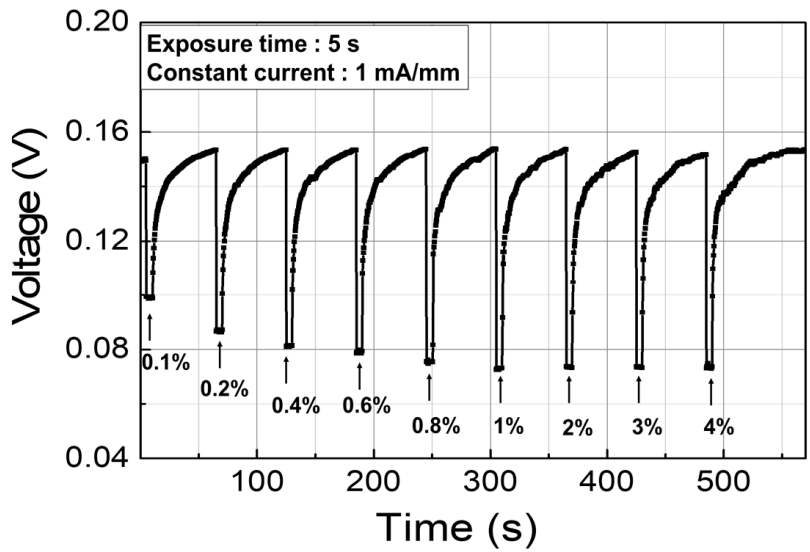

(a)

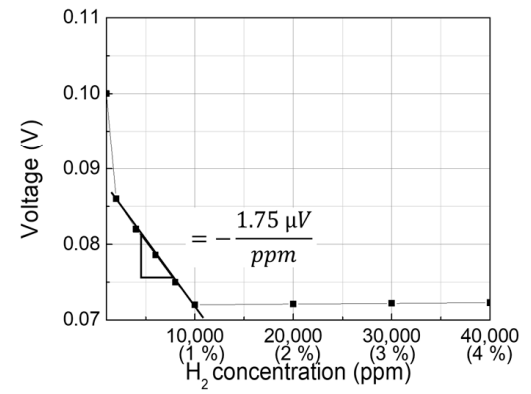

(b)

Figure 8. (a) Response characteristics as a function of hydrogen concentration and (b) their corresponding response plot.

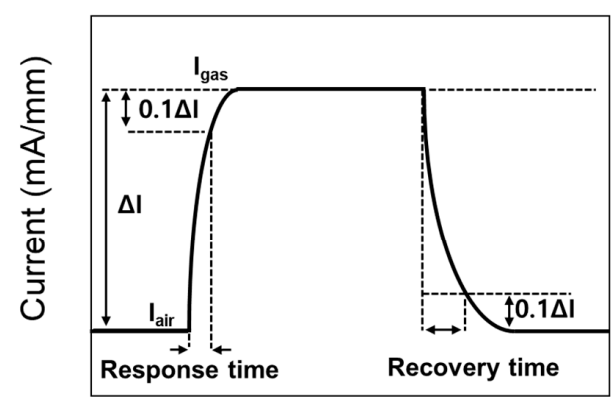

Time (s)

(a)

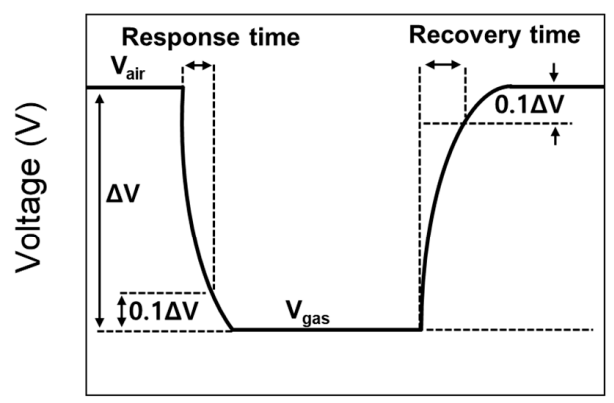

Time (s)

(b)

Figure 9. Definition of response time and recovery time for (a) constant voltage bias mode and (b) constant current bias mode.

Table 1. Comparison of sensor characteristics with other reports.

\begin{tabular}{|c|c|c|c|c|c|c|c|}
\hline Sensor Platform & Temp. & $\begin{array}{c}\text { Hydrogen } \\
\text { Concentration }\end{array}$ & $\begin{array}{l}\text { Response } \\
\text { Time }\end{array}$ & $\begin{array}{l}\text { Recovery } \\
\text { Time }\end{array}$ & $\begin{array}{c}\text { Sensor } \\
\text { Response }\end{array}$ & $\begin{array}{c}\text { Power } \\
\text { Consumption }\end{array}$ & Ref. \\
\hline $\begin{array}{c}\text { Diode } \\
\text { (AlGaAs) }\end{array}$ & Room temp. & $1 \%$ & $58 \mathrm{~s}$ & - & $155.9 \%$ & - & [23] \\
\hline $\begin{array}{l}\text { Diode } \\
(\mathrm{GaN})\end{array}$ & Room temp. & $1 \%$ & $15 \mathrm{~s}$ & $19 \mathrm{~s}$ & $1 \times 10^{5 \%}$ & - & [24] \\
\hline $\begin{array}{l}\text { Diode } \\
(\mathrm{GaN})\end{array}$ & $200^{\circ} \mathrm{C}$ & $4 \%$ & - & - & $7 \times 10^{8 \%}$ & - & [19] \\
\hline $\begin{array}{l}\text { Diode } \\
(\mathrm{GaN})\end{array}$ & $300^{\circ} \mathrm{C}$ & $0.081 \%$ & $25.1 \mathrm{~s}$ & $34.1 \mathrm{~s}$ & $0.11 \%$ & - & [25] \\
\hline $\begin{array}{c}\text { Diode } \\
(\mathrm{AlGaN} / \mathrm{GaN})\end{array}$ & Room temp. & $0.05 \%$ & - & - & $2.4 \%$ & - & [26] \\
\hline $\begin{array}{c}\text { Diode } \\
(\mathrm{AlGaN} / \mathrm{GaN})\end{array}$ & Room temp. & $4 \%$ & - & - & $3700 \%$ & $382 \mathrm{~W} / \mathrm{cm}^{2}$ & [27] \\
\hline $\begin{array}{c}\text { MOS diode } \\
(\mathrm{AlGaN} / \mathrm{GaN})\end{array}$ & Room temp. & $10 \%$ & $\sim 30 \mathrm{~s}$ & - & - & $5333 \mathrm{~W} / \mathrm{cm}^{2}$ & [28] \\
\hline $\begin{array}{l}\text { FET } \\
(\mathrm{Si})\end{array}$ & $150^{\circ} \mathrm{C}$ & $0.5 \%$ & $18 \mathrm{~s}$ & $19 \mathrm{~s}$ & - & $\begin{array}{c}35.8 \mathrm{~mW} \\
\text { (Sensor area N/A) }\end{array}$ & [29] \\
\hline $\begin{array}{c}\text { FET } \\
(\mathrm{AlGaN} / \mathrm{GaN})\end{array}$ & $200^{\circ} \mathrm{C}$ & $4 \%$ & $3 \mathrm{~s}$ & - & $72 \%$ & $3.93 \mathrm{~W} / \mathrm{cm}^{2}$ & [30] \\
\hline $\begin{array}{c}\text { FET } \\
(\mathrm{AlGaN} / \mathrm{GaN}) \\
\text { Constant voltage }\end{array}$ & $200^{\circ} \mathrm{C}$ & $4 \%$ & $<0.4 \mathrm{~s}$ & $12.4 \mathrm{~s}$ & $80 \%$ & $347 \mathrm{~W} / \mathrm{cm}^{2}$ & This work \\
\hline $\begin{array}{c}\text { FET } \\
(\mathrm{AlGaN} / \mathrm{GaN}) \\
\text { Constant current }\end{array}$ & $200^{\circ} \mathrm{C}$ & $4 \%$ & $<0.4 \mathrm{~s}$ & $27.2 \mathrm{~s}$ & $120 \%$ & $0.54 \mathrm{~W} / \mathrm{cm}^{2}$ & This work \\
\hline
\end{tabular}




\section{Conclusions}

A Pd-functionalized hydrogen sensor fabricated on an AlGaN/GaN-on-Si heterostructure platform was investigated under different operation conditions. The optimum reaction temperature was $200^{\circ} \mathrm{C}$. Constant voltage and current mode operations were investigated with different bias conditions. While the constant voltage bias mode operation exhibited more stable operation in the high voltage saturation regime, the constant current bias mode operation exhibited more stable operation in the low current regime. When determining the bias conditions, it is recommended to choose the stable response regime. The constant current bias mode operation in the low current regime is highly recommended considering both stability and standby power consumption. A prototype sensor was fabricated and evaluated in this study and exhibited excellent sensing characteristics with stable operation. The standby power consumption was extremely low (i.e., $0.15 \mathrm{~mW} / \mathrm{mm}$ ) owing to the low standby current and voltage levels. Such excellent characteristics resulted from the stable current bias mode operation in conjunction with the capability for high-temperature operation.

Author Contributions: Experiment, formal analysis, and writing, J.-H.C.; resources, H.K.; investigation and review, H.-K.S.; methodology and supervision, H.-Y.C.

Funding: This work was supported by the Korea Electric Power Corporation (Grant No. R18XA02) and the Basic Science Research Program (Grant No. 2015R1A6A1A03031833, 2019R1A2C1008894) through the National Research Foundation of Korea (NRF).

Acknowledgments: Authors would like to thank Ji-Hyung Lee for his assistance in sensor measurement.

Conflicts of Interest: The authors declare no conflict of interest.

\section{References}

1. Das, D. Advances in biohydrogen production process: An approach towards commercialization. Int. J. Hydrogen Energy 2009, 34, 7349-7357. [CrossRef]

2. Ahluwalia, R.K.; Wang, X.; Rousseau, A.; Kumar, R. Fuel economy of hydrogen cell vehicles. J. Power Sources 2004, 130, 192-201. [CrossRef]

3. Steinberg, M.; Cheng, H.C. Modern and prospective technologies for hydrogen production from fossil fuels. Int. J. Hydrogen Energy 1989, 14, 797-820. [CrossRef]

4. Kanungo, J.; Saha, H.; Basu, S. Porous silicon hydrogen sensor at room temperature: The effect of surface modification and noble metal contacts. Sens. Transducers 2009, 103, 102-108.

5. Salehi, A.; Nikfarjam, A.; Kalantari, D.J. Pd/porous-GaAs Schottky contact for hydrogen sensing application. Sens. Actuators B 2006, 113, 419-427. [CrossRef]

6. Kim, S.; Choi, J.; Jung, M.; Joo, S.; Kim, S. Silicon carbide-based hydrogen gas sensors for high-temperature applications. Sensors 2013, 13, 13575-13583. [CrossRef] [PubMed]

7. Hassan, J.J.; Mahdi, M.A.; Chin, C.W.; Abu-Hassan, H.; Hassan, Z. Room temperature hydrogen gas sensor based on $\mathrm{ZnO}$ nanorod arrays grown on a $\mathrm{SiO}_{2} / \mathrm{Si}$ substrate via microwave-assisted chemical solution method. J. Alloys Compd. 2013, 546, 107-111. [CrossRef]

8. Shaposhnik, D.; Pavelko, R.; Llovet, E.; Gispert-Guirado, F.; Vilanova, X. Hydrogen sensors on the basis of $\mathrm{SnO}_{2}-\mathrm{TiO}_{2}$ systems. Procedia Eng. 2011, 25, 1133-1136. [CrossRef]

9. Li, Z.; Yao, Z.; Haidry, A.A.; Plecenik, T.; Xie, L.; Sun, L.; Fatima, Q. Resistive-type hydrogen gas sensor based on $\mathrm{TiO}_{2}$ : A review. Int. J. Hydrogen Energy 2018, 43, 21114-21132. [CrossRef]

10. Hao, L.; Liu, Y.; Du, Y.; Chen, Z.; Han, Z.; Xu, Z.; Zhu, J. Highly enhanced $\mathrm{H}_{2}$ sensing performance of few-layer $\mathrm{MoS}_{2} / \mathrm{SiO}_{2} / \mathrm{Si}$ heterojunctions by surface decoration of Pd nanoparticles. Nanoscale Res. Lett. 2017, 12, 1-10. [CrossRef]

11. Chung, G.; Cha, H.Y.; Kim, H. Enhanced hydrogen sensitivity of AlGaN/GaN heterojunction gas sensors by GaN-cap layer. Electron. Lett. 2018, 54, 896-897. [CrossRef]

12. Burk, A.A., Jr.; O’Loughlin, M.J.; Siergiej, R.R.; Agarwal, A.K.; Sriram, S.; Clarke, R.C.; MacMillan, M.R.; Balakrishna, V.; Brandt, C.D. SiC and GaN wide bandgap semiconductor materials and devices. Solid-state Electron. 1999, 43, 1459-1464. [CrossRef] 
13. Chen, J.T.; Persson, I.; Nilsson, D.; Hsu, C.W.; Palisaitis, J.; Forsberg, U.; Persson, P.O.Å.; Janzen, E. Room temperature mobility above $2200 \mathrm{~cm}^{2} / \mathrm{V} \cdot \mathrm{s}$ of two-dimensional electron gas in a sharp-interface AlGaN/GaN heterostructure. Appl. Phys. Lett. 2015, 106, 251601. [CrossRef]

14. Li, Y.; Cheng, Y.T. Hydrogen diffusion and solubility in palladium thin films. Int. J. Hydrogen Energy 1996, 21, 281-291. [CrossRef]

15. Safarik, D.K.; Schwarz, R.B.; Paglieri, S.N.; Quintana, R.L.; Tuggle, D.G.; Byler, D.D. Composition dependence of the elastic constants of $\beta$-phase and $(\alpha+\beta)$-phase $\mathrm{PdH}_{\mathrm{x}}$. Ultrasonics 2010, 50, 155-160. [CrossRef]

16. Khanuja, M.; Shrestha, S.; Metha, B.R.; Kala, S.; Kruis, F.E. Magnitude and time response of electronic and topographical changes during hydrogen sensing in size selected palladium nanoparticles. J. Appl. Phys. 2011, 110, 014318. [CrossRef]

17. Fisser, M.; Badcock, A.B.; Teal, P.D.; Hunze, A. Optimizing the sensitivity of palladium based hydrogen sensors. Sens. Actuators, B: Chem 2018, 259, 10-19. [CrossRef]

18. Conde, J.J.; Marono, M.; Sanchez-Hervas, J.M. Pd-Based Membranes for Hydrogen Separation Review of Alloying Elements and Their Influence on Membrane Properties. Sep. Purif. Rev. 2017, 46, $152-177$. [CrossRef]

19. Baik, K.H.; Kim, J.; Jang, S. Highly sensitive nonpolar a-plane GaN based hydrogen diode sensor with textured active area using photo-chemical etching. Sens. Actuators B Chem. 2017, 238, 462-467. [CrossRef]

20. Lee, I.H.; Kim, Y.H.; Chang, Y.J.; Shin, J.H.; Jang, T.; Jang, S.Y. Temperature-dependent Hall Measurement of AlGaN/GaN Heterostuctures on Si Substrates. J. Korean. Phys. Soc. 2015, 66, 61-64. [CrossRef]

21. D'Amico, A.; Di Natale, C. A Contribution on Some Basic Definitions of Sensors Properties. IEEE. Sens. J. 2001, 1, 183-190. [CrossRef]

22. Lin, Y.; Deng, P.; Nie, Y.; Hu, Y.; Xing, L.; Zhang, Y.; Xue, X. Room-temperature self-powered ethanol sensing of a $\mathrm{Pd} / \mathrm{ZnO}$ nanoarray nanogenerator driven by human finger movement. Nanoscale 2014, 6, 4604-4610. [CrossRef] [PubMed]

23. Tsai, Y.Y.; Lin, K.W.; Lu, C.T.; Chen, H.I.; Chuang, H.M.; Chen, C.Y.; Cheng, C.C.; Liu, W.C. Investigation of Hydrogen-Sensing Properties of Pd/AlGaAs-Based Schottky Diodes. IEEE Trans. Electron. Devices 2003, 50, 2532-2539. [CrossRef]

24. Liu, I.P.; Chang, C.H.; Ke, B.Y.; Lin, K.W. Study of a GaN Schottky diode based hydrogen sensor with a hydrogen peroxide oxidation approach and platinum catalytic metal. Int. J. Hydrogen Energy 2019, 44, 32351-32361. [CrossRef]

25. Chen, G.; Choi, A.H.W.; Lai, P.T.; Tang, W.M. Schottky-diode hydrogen sensor based on InGaN/GaN multiple quantum well. J. Vac. Sci. Technol. B. 2014, 32, 011212. [CrossRef]

26. Anderson, T.J.; Wang, H.T.; Kang, B.S.; Ren, F.; Pearton, S.J.; Osinsky, A.; Dabiran, A.; Chow, P.P. Effect of bias voltage polarity on hydrogen sensing with AlGaN/GaN Schottky diodes. Appl. Surf. Sci. 2008, 255, 2524-2526. [CrossRef]

27. Jang, S.; Son, P.; Kim, J.; Lee, S.N.; Baik, K.H. Hydrogen sensitive Schottky diode using semipolar (11 $\overline{2} 2)$ AlGaN/GaN heterostructures. Sens. Actuators B 2016, 222, 43-47. [CrossRef]

28. Kang, B.S.; Ren, F.; Gila, B.P.; Abernathy, C.R.; Pearton, S.J. AlGaN/GaN-based metal-oxide-semiconductor diode-based hydrogen sensor. Appl. Phys. Lett. 2004, 84, 1123-1125. [CrossRef]

29. Kim, B.J.; Yoon, J.H.; Kim, J.S. Gas sensing characteristics of low-powered dual MOSFET hydrogen sensors. Mater. Chem. Phys. 2013, 142, 594-599. [CrossRef]

30. Choi, J.H.; Jo, M.G.; Han, S.W.; Kim, H.; Jang, S.; Kim, S.H.; Kim, J.S.; Cha, H.Y. Hydrogen sensors Pd-functionalised $\mathrm{AlGaN} / \mathrm{GaN}$ heterostructure with high sensitivity and low-power consumption. Electron. Lett. 2017, 53, 1200-1202. [CrossRef]

(C) 2019 by the authors. Licensee MDPI, Basel, Switzerland. This article is an open access article distributed under the terms and conditions of the Creative Commons Attribution (CC BY) license (http://creativecommons.org/licenses/by/4.0/). 